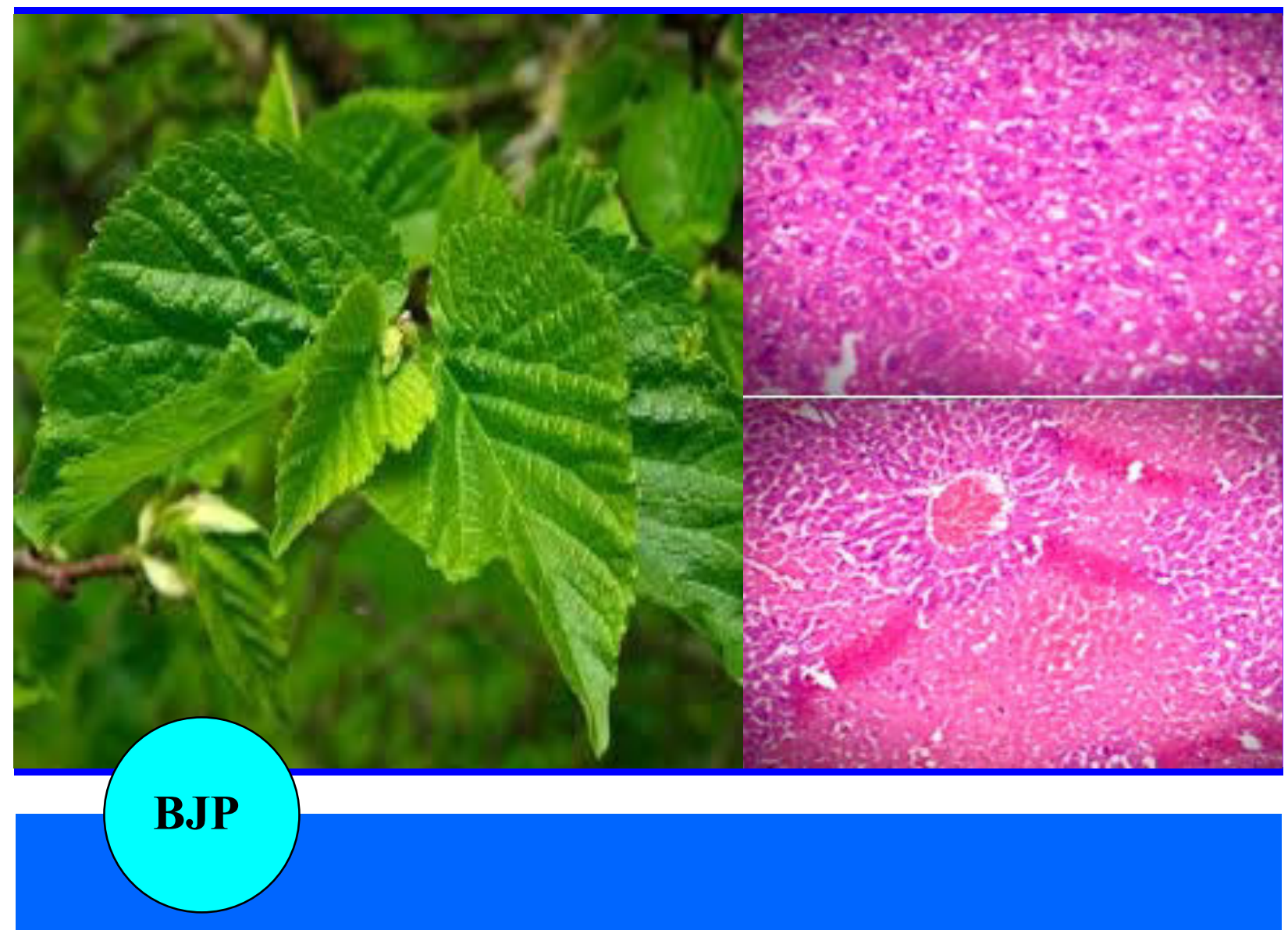

Bangladesh Journal of Pharmacology

Research Article

Hepatoprotective activity of aqueous methanolic extract of Morus nigra against paracetamol-induced hepatotoxicity in mice 


\title{
Hepatoprotective activity of aqueous methanolic extract of Morus nigra against paracetamol-induced hepatotoxicity in mice
}

\author{
Tauqeer Hussain Mallhi', M. Imran Qadir'1, Yusra Habib Khan² and Muhammad Ali3 \\ ${ }^{1}$ College of Pharmacy, GC University, Faisalabad, Pakistan; ${ }^{2}$ School of Pharmaceutical Sciences, University Sains \\ Malaysia, Penang Pulau, Malaysia; ${ }^{3}$ Institute of Molecular Biology and Biotechnology, Bahauddin Zakariya \\ University, Multan, Pakistan.
}

\begin{tabular}{|c|c|}
\hline \multicolumn{2}{|l|}{ Article Info } \\
\hline Received: & 8 January 2014 \\
\hline Accepted: & 13 January 2014 \\
\hline Available Online: & 7 February 2014 \\
\hline \multicolumn{2}{|c|}{ DOI: 10.3329/bjp.v9i1.17337 } \\
\hline \multicolumn{2}{|c|}{$\begin{array}{l}\text { Cite this article: } \\
\text { Mallhi TH, Qadir MI, Khan YH, Ali } \\
\text { M. Hepatoprotective activity of aque- } \\
\text { ous methanolic extract of Morus nigra } \\
\text { against paracetamol-induced hepato- } \\
\text { toxicity in mice. Bangladesh J Phar- } \\
\text { macol. 2014; 9: 60-66. }\end{array}$} \\
\hline
\end{tabular}

\begin{abstract}
Morus nigra (Family Moraceae) is traditionally used injaundice, diabetes, hypertension, cough, fever and cancer. The current study was conducted to determine hepatoprotective activity of aqueous methanolic extract of leaves of M. nigra. Two doses of 250 and $500 \mathrm{mg} / \mathrm{kg}$ p.o showed that extract of $M$. nigra produced significant $(\mathrm{p}<0.001)$ reduction in liver enzymes $(\mathrm{ALT}, \mathrm{AST}$, ALP) and total bilirubin induced by paracetamol and the results are comparable to silymarin $(\mathrm{p}<0.001)$. Results were supported by histopathological investigations, phytochemical screening and detection of active constituents by HPLC. The current study showed that aqueous methanolic extract of $M$. nigra possess hepatoprotective activity that might be due to quercetin, luteolin and isorhamnetin. It was concluded from this study that $M$. nigra has hepatoprotective activity against paracetamol induced liver injury in mice.
\end{abstract}

\section{Introduction}

The problem of resistance and tolerance to the existing drugs has created a decreased efficacy of these drugs in use. This problem has been tried to be overcome by increasing the drug delivery to the target site by the use of polymers (Khalid et al., 2009; Hussain et al., 2011) or through nanotechnology (Naz et al., 2012; Ehsan et al., 2012), synthesis of new drugs, either by the use of proteomics (Qadir, 2011), or synthesis from lactic acid bacteria (Masood et al., 2011), or marine microorganisms (Javed et al., 2011). However, now-a-days, the trend is also being changed to the use of herbal products or extracts to control the diseases. The plant kingdom still holds many species containing substances of medicinal value which have yet to be discovered: large numbers of plants are constantly being screened for their possible pharmacological value particularly for their anti-inflammatory (Qadir, 2009), hypotensive (Qadir, 2010), hypoglycemic, amoebicidal, anti-fertility, cytotoxic, antibiotic (Amin et al., 2012), spasmolytic, bronchodilator (Janbaz et al., 2013), antioxidant (Janbaz et al., 2012) and hepatoprotective properties (Ahmad et al., 2012). Many plants have been identified as hepatoprotective like Trianthema decandra (Balamurugan and Muthusamy, 2008), Cocculus hirsutus (Thakare et al., 2009), Carica papaya (Sadeque and Begum, 2010), Carissa spinarum (Hegde and Joshi, 2010), Convolvulus arvensis (Ali et al., 2013), Dodonaea viscosa (Khan et al., 2013), Trichodesma sedgwickianum (Saboo et al., 2013), Ipomoea staphylina (Bag and Mumtaz, 2013) and Khamira Gaozaban Ambri Jadwar Ood Saleeb Wala (Akhtar et al., 2013).

Morus nigra (Moraceae) widely distributed in Asia, Africa, Europe, and America. It is commonly as Black Mulberry (English) and Shah-toot (Hindi/Urdu). Pharmacologically it has been reported that $M$. nigra is antioxidant (Ozgenet al., 2009), anti-nociceptive (Padilhaet al., 2009), anti-inflammatory (Padilhaet al., 2010), antidiabetic (Husseinzadehet al., 1999), antibacterial (Mazimbaet al., 2011), cardiac depressant (Malik et al., 2012), effective for maternal health (Volpetoet al., 2011), vermifuge and anti-cancer (Kumar and Chauhan, 2008). 
Important phytoconstituents e.g. flavonoids, alkaloids and phenols have been reported in this plant (Malik et al., 2012; Özgen et al., 2009). Most of the flavonoids have hepatoprotective activity (Ali et al., 2013). Traditionally $M$. nigra is worthwhile to cure jaundice (Abbasiet al., 2009). Phytochemical profile and traditional use of M. Nigra in liver injury appealed us to scientifically evaluate its hepatoprotective potential.

\section{Materials and Methods}

Selection and collection of plant: The plant was selected on the basis of its traditional and phytochemical profile and collected from Allied hospital, Agriculture University, Local Nursery Farms from Faisalabad and identified by Dr. Mansoor Hameed, Associate Professor, Department of Botany, University of Agriculture Faisalabad. For future reference plant was kept in the department herbarium.

Preparation of plant extract: The leaves of the plant were washed and put to dry under shade which were finally grounded to powder $(3.2 \mathrm{~kg})$ with the help of commercial grinder. Powdered leaves were soaked in $8 \mathrm{~L}$ aqueous methanol (70:30) for 7-10 days with occasional shak -ing. Solution was filtered through muslin cloth and marc was pressed to achieve all filtrate. The filtrate was evaporated with the help of rotary evaporator at $70^{\circ} \mathrm{C}$. At the end of evaporation dark brownish jelly like paste was obtained that was stored in amber colored glass bottle for further analysis.

Experimental animals: Swiss albino mice of both sexes weighing 22-35 g were used for study and all were kept in animal house of College of Pharmacy, GC University Faisalabad, Pakistan. The animals were housed in cages and maintained under standard laboratory conditions (temperature $25 \pm 2^{\circ} \mathrm{C}$ ) with dark and light cycle $(12 / 12$ hours). The acclimatization period was lasted for 10 days (Iwalokunet al., 2006). These were fed with standardized pellet diet and water ad libitum. All the experimental methods and materials were reviewed and approved by supervisory committee of College of Pharmacy, GC University Faisalabad. Research was con -ducted in accordance with the internationally accepted principles for laboratory animal use and cares as found in for example the European Community guidelines (EEC Directive of 1986; 86/609/EEC) or the US guidelines.

Experimental protocol: All the animals were divided into five groups having 5 animals each. Group I was control, receiving distilled water only, for seven days. Group II served as paracetamol control, receiving paracetamol p.o. $250 \mathrm{mg} / \mathrm{kg}$ dissolved in water for 7 days. Group III, silymarin control in which silymarin was given as reference drug $50 \mathrm{mg} / \mathrm{kg}$ daily for 7 days and paracetamol was administered 3 hours after silymarin (Girishet al., 2009). Group IV Received aqueous methanolic
(70:30) extract of $M$. nigra (AMMN) at doses $250 \mathrm{mg} / \mathrm{kg}$ p.o. for 7 days and received paracetamol $250 \mathrm{mg} / \mathrm{kg} 3$ hours after extract dose. Group V received aqueous methanolic extract of $M$. nigra (AMMN) at doses 500 $\mathrm{mg} / \mathrm{kg}$ p.o. for 7 days and received paracetamol 250 $\mathrm{mg} / \mathrm{kg} 3$ hours after extract dose (Sabir and Rocha, 2008). Experimental protocol was reviewed by Supervisory and Ethical committee for animal research of College of Pharmacy of Institute.

All the animals were fasted for 12 hours and anesthetized with light chloroform and sacrificed by cervical decapitation on $8^{\text {th }}$ day at same time of last day dose. Blood samples were collected in eppendorf tubes for serum preparation. Hepatotoxicity was indicated by a significant elevation in the activity of ALT, AST, ALP and total bilirubin (TBR) in acetaminophen-challenged mice compared with the controls throughout the experiment (Vimal and Devaki, 2004).

Biochemical investigation: After collection of blood, clotted blood was subjected to centrifugation for separation of serum at the rate of 4,000 for $20 \mathrm{~min}$. Liver function tests e.g. ALT, AST, ALP and total bilirubin was evaluated by adopting standard operating procedures (Shanmugasundaram and Venkataraman, 2006).

Histopathological studies: The liver from animals was separated and placed in 10\% buffered formalin (4\% formaldehyde in phosphate buffer solution). The dyes used for histopathological examination was Hematoxylin and Eosin for nuclei and cytoplasm staining into blue/purple and pink respectively. Summary of methodology is shown in Figure 1.

Phytochemical screening: The preliminary phytochemical screening of various active compounds were accomplished by methods used by Farhanet al., 2012 where filtered ethanolic extract $(70 \%)$ and powdered plant were used as shown in Table I.

The results of phytochemical screening have been shown in Table II. Qualitative determination of flavornoid contents were determined by HPLC analysis of aqueous methanolic extract used in this study.

HPLC analysis for determination of phytoconstituents: For qualitative separation of compounds, SYKAM HPLC system was used equipped with S-1122 Solvent Delivery System, S-3210 UV/VIS Detector, S-5111 Injector Valve Bracket, pump (1500 series), Column oven and pre-packed C-18 column $(250 \times 4.5 \mathrm{~mm}, 5$ um particle size). For sample injection glass syringe of $25 \mu \mathrm{L}$ was used. Data was analyzed by using SampleClarity Light software installed in Laboratory computer attached with HP inkjet printer. HPLC protocol for determination of Flavonoids was followed according to Saddiqeet al., (2011) in which standard solutions were prepared in HPLC grade methanol at concentration $100 \mu \mathrm{g} / \mathrm{mL}$ and were stored in refrigerator at $-20^{\circ} \mathrm{C}$. All standard solutions were filtered by using $0.45 \mu \mathrm{m}$ filters and further dilutions were made by adding methanol if needed. For 


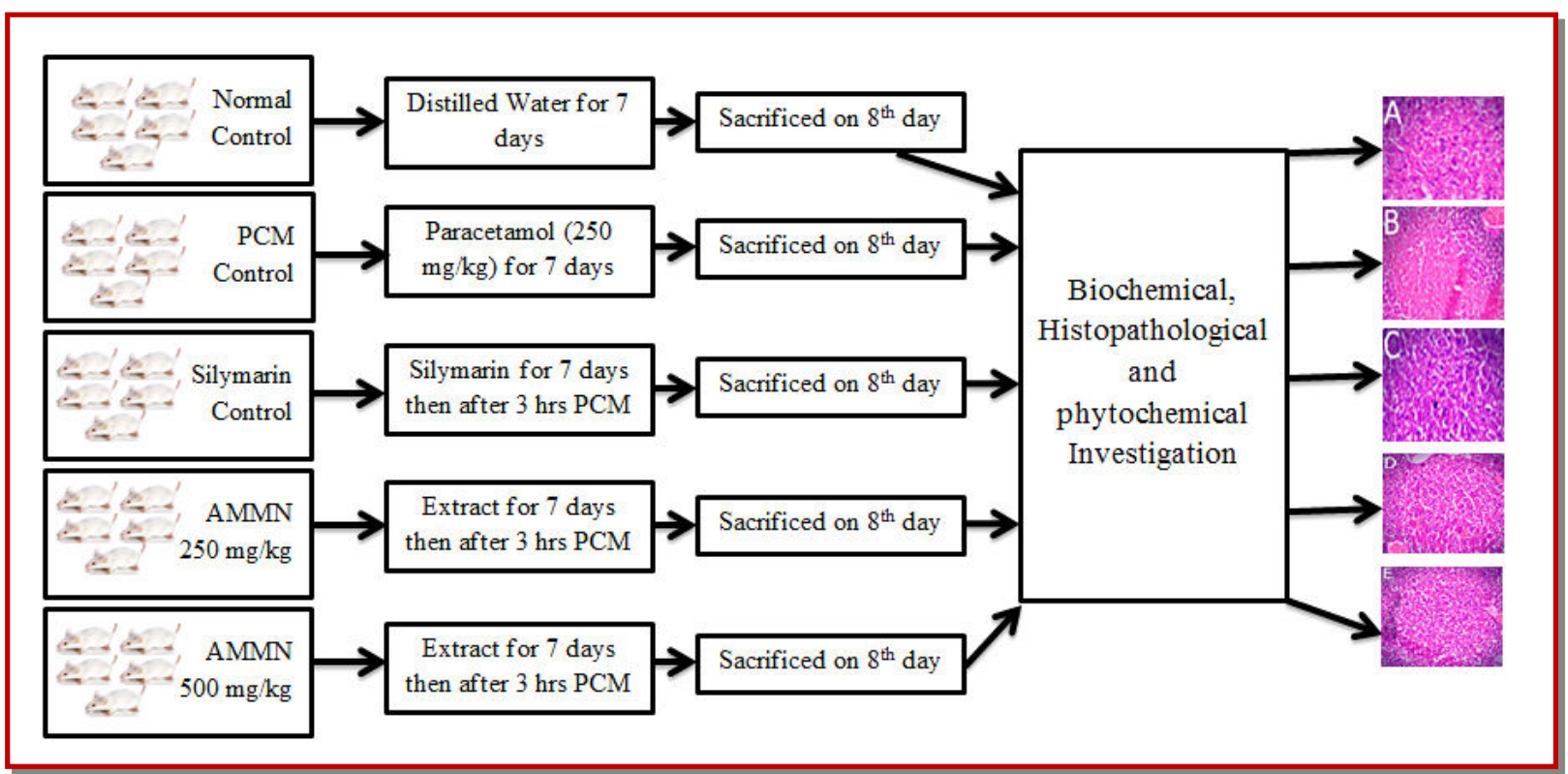

Figure 1: Summary of study methodology

\section{Table I}

Protocols for phytochemical screening of Morus nigra

\begin{tabular}{|c|c|c|}
\hline Detection & Procedure & Observation \\
\hline Tannins & Ferric chloride reagent $(\mathrm{FeCl} 3) 1 \%$ drops were added to $10 \mathrm{ml}$ of the extract & Appearance blue color \\
\hline Resins & $20 \mathrm{~mL} \mathrm{HCl} 4 \%$ were added in $10 \mathrm{~mL}$ of extract & Turbidity \\
\hline Coumarins & $\begin{array}{c}5 \mathrm{~mL} \text { of extract in a test tube was covered by a filter paper saturated in } \\
\mathrm{NaOH} \text { and was putted in water bath, boiled for } 10 \mathrm{~min} \text {. The filter paper was } \\
\text { taken and exposed to UV light }\end{array}$ & $\begin{array}{l}\text { Appearance green bright yellow } \\
\text { color }\end{array}$ \\
\hline Saponins & Extract in test tube was shacked for 5 min using a vortex & Appearance of big foamy \\
\hline Alkaloids & $\begin{array}{l}0.2 \mathrm{~g} \text { powder of the plant was dissolved in } 10 \mathrm{~mL} \text { of } \mathrm{HCl} 1 \% \text { and they were } \\
\text { transferred to a water bath for few min. } 1 \mathrm{~mL} \text { of the filtrated extract was } \\
\text { treated with } 2-4 \text { drops of Dragendorff's reagent }\end{array}$ & Orange reddish precipitation \\
\hline Phenols & $\begin{array}{l}\text { In beakers, } 5 \mathrm{~mL} \text { of each extract was taken and } 1 \mathrm{~mL} \text { of } \mathrm{FeCl}_{3} 1 \% \text { and } 1 \mathrm{~mL} \\
\text { of } \mathrm{K}_{3}\left(\mathrm{Fe}(\mathrm{CN})_{6}\right) 1 \% \text { were added }\end{array}$ & Fresh radish blue color \\
\hline $\begin{array}{l}\text { Terpe- } \\
\text { noids }\end{array}$ & $\begin{array}{c}1 \mathrm{~mL} \text { of acetic anhydride and } 2 \mathrm{~mL} \text { of concentrated sulphuric acid were } \\
\text { added to beakers containing } 1 \mathrm{~mL} \text { of extract }\end{array}$ & Reddish brown on the interface \\
\hline $\begin{array}{l}\text { Volatile } \\
\text { oils }\end{array}$ & $\begin{array}{l}10 \mathrm{~mL} \text { of extract was filtered by filter paper till saturation and then exposed } \\
\text { for UV light }\end{array}$ & $\begin{array}{c}\text { Appearance of a bright pinkish } \\
\text { color }\end{array}$ \\
\hline Flavonoids & $\begin{array}{l}\text { Two solutions A and B from plant extract were prepared. The solution A } \\
\text { contains } 5 \mathrm{~mL} \text { of ethanolic extract. The solution B consists of } 5 \mathrm{~mL} \text { of etha- } \\
\text { nolic solvent added to } 5 \mathrm{~mL} \text { of } \mathrm{KOH} 50 \% \text {. Then the two solutions A and B } \\
\text { were mixed together }\end{array}$ & Appearance of yellow color \\
\hline
\end{tabular}

concentration $100 \mu \mathrm{g} / \mathrm{mL}, 0.001 \mathrm{~g}$ extract was weighed on sensitive weight machine and dissolved in $10 \mathrm{~mL}$ of methanol (HPLC grade). All the prepared samples were stored in refrigerator at $4^{\circ} \mathrm{C}$ and filtered through 0.45 $\mu \mathrm{m}$ filters before HPLC analysis. Acetonitrile and water of HPLC grades were used to prepare mobile phase in 1:1 proportion. Final solution of mobile phase was acidi -fied with $1 \%$ acetic acid by adding few drops. Mobile phase was filtered through $0.45 \mu \mathrm{m}$ filters before use. Mobile phase was run at flow rate $1 \mathrm{~mL} / \mathrm{min}$ and com- pounds were detected at $254 \mathrm{~nm}$. HPLC system was thoroughly washed with methanol before use for about one hour. After analysis retention times was compared to that of standards for detection of flavonoid contents in aqueous methanolic extract (Saddiqe et al., 2011).

Statistical analysis: All the data were subjected to oneway ANOVA (Analysis of variance) by SPSS version 17.0 (SPSS Inc., Chicago, IL, USA) for statistical analysis. Results were represented as mean $\pm \mathrm{SE}$. 
Table II

Effect of aqueous methanolic extract of Morus nigra (AMMN) on liver enzymes and total bilirubin

\begin{tabular}{|lcccc|}
\hline Treatment Groups & ALT (IU/L) & AST (IU/L) & ALP (IU/L) & TBR $(\mathrm{g} / \mathrm{dL})$ \\
\hline Normal (D/W) & $32.8 \pm 2.1$ & $36.5 \pm 3.6$ & $216.2 \pm 10.0$ & $0.9 \pm 0.0$ \\
Paracetamol Control $(250 \mathrm{mg} / \mathrm{kg})$ & $112.1 \pm 4.2$ & $101.2 \pm 9.2$ & $413.4 \pm 21.7$ & $2.0 \pm 0.2$ \\
Silymarin $(50 \mathrm{mg} / \mathrm{kg})+$ Paracetamol & $41.6 \pm 3.1^{\mathrm{b}}$ & $39.8 \pm 07.8^{\mathrm{b}}$ & $266.4 \pm 32.7^{\mathrm{a}}$ & $0.9 \pm 0.1^{\mathrm{a}}$ \\
AMMN $(250 \mathrm{mg} / \mathrm{kg})+$ Paracetamol & $50.6 \pm 7.2^{\mathrm{b}}$ & $41.8 \pm 5.0^{\mathrm{b}}$ & $288.0 \pm 10.1^{\mathrm{a}}$ & $0.9 \pm 0.1^{\mathrm{a}}$ \\
AMMN $(500 \mathrm{mg} / \mathrm{kg})+$ Paracetamol & $45.4 \pm 5.0^{\mathrm{b}}$ & $40.6 \pm 6.4^{\mathrm{b}}$ & $272.1 \pm 11.2^{\mathrm{b}}$ & $0.9 \pm 0.1^{\mathrm{a}}$ \\
${ }^{\mathrm{a}}<0.01,{ }^{\mathrm{b}}<0.001$ & & & & \\
\hline
\end{tabular}

Table III

Phytochemical Screening of leaves of Morus nigra

\begin{tabular}{|cc|}
\hline Active compounds & Leaves of Morus nigra \\
\hline Phenols & ++ \\
Flavonoids & ++ \\
Saponins & + \\
Alkaloids & + \\
Resins & - \\
Tannins & - \\
Coumarines & - \\
Volatile Oils & - \\
Terpinoids & - \\
$(+++)$ high amount after added of reagent immediately; $(++)$ mod- \\
erate amount after 5 min of reagent added; (+) low amount after 10 \\
min of reagent added and $(-)$ absent of active compound after 20 \\
min
\end{tabular}

\section{Results}

The normal ALT value $32.8 \pm 2.1 \mathrm{IU} / \mathrm{L}$ elevated to 112.1 $\pm 4.2 \mathrm{IU} / \mathrm{L}$ by paracetamol intoxication. After administration of 250 and $500 \mathrm{mg} / \mathrm{kg}$ of aqueous methanolic extract of $M$. nigrathe mean ALT values were observed as $50.6 \pm 7.2 \mathrm{IU} / \mathrm{L}(\mathrm{p}<0.001)$ and $45.4 \pm 5.0 \mathrm{IU} / \mathrm{L}$ $(p<0.001)$ respectively which was comparable to silymarin control $41.6 \pm 3.1 \mathrm{IU} / \mathrm{L}(\mathrm{p}<0.001)$. The normal mean value of AST $36.5 \pm 3.6 \mathrm{IU} / \mathrm{L}$ was elevated to $101.2 \pm 9.2 \mathrm{IU} / \mathrm{L}$ with paracetamol ingestion which was reduced to $41.8 \pm 5.0 \mathrm{IU} / \mathrm{L}(\mathrm{p}<0.001)$ and $40.6 \pm 6.4 \mathrm{IU} / \mathrm{L}$ $(p<0.001)$ with doses of 250 and $500 \mathrm{mg} / \mathrm{kg}$ of aqueous methanolic extract respectively. AST reduction is also comparable to that of silymarin control $39.8 \pm 7.8 \mathrm{IU} / \mathrm{L}$ $(\mathrm{p}<0.001)$. The normal mean value of ALP $216.2 \pm 10.0$ $\mathrm{IU} / \mathrm{L}$ increased by administration of paracetamol to $413.4 \pm 21.8 \mathrm{IU} / \mathrm{L}$. Aqueous methanolic extract 250 and $500 \mathrm{mg} / \mathrm{kg}$ brought the enzyme value of ALP to the $288.0 \pm 10.1 \mathrm{IU} / \mathrm{L}(\mathrm{p}<0.01)$ and $272.1 \pm 11.2 \mathrm{IU} / \mathrm{L}$ $(\mathrm{p}<0.001)$ respectively which was comparable to the standard silymarin $266.4 \pm 32.7 \mathrm{IU} / \mathrm{L}(\mathrm{p}<0.01)$. Normal mean value of total bilirubin (TBR) in mice was raised from $0.9 \pm 0.03$ to $2.1 \pm 0.2 \mathrm{~g} / \mathrm{dL}$ by paracetamol administration. When these animals were treated with 250 and $500 \mathrm{mg} / \mathrm{kg}$ of aqueous methanolic extract the total bilirubin reduced to $0.2 \pm 0.1 \mathrm{~g} / \mathrm{dL}(\mathrm{p}<0.01)$ and 0.9 $\pm 0.1 \mathrm{~g} / \mathrm{dL} \quad(\mathrm{p}<0.01)$ respectively which were comparable to that of silymarin control $0.9 \pm 0.1 \mathrm{~g} / \mathrm{dL}$ $(\mathrm{p}<0.01)$. There were no significant differences in effects between two doses of the extract, except ALP values as shown in Table II.

Histopathological examination of liver sections also supports biochemical investigation as shown in Figure 2. (A) Normal liver cells (B) PCM ingestion cause inflamed and necrotic cells with marked sinusoidal constriction (C) and recovery of cells with silymarin (D, E). Recovery of cells were observed with both doses of extracts. Effects of aqueous methanolic extract can be compared with silymarin as both showing improvement in hepatocytes necrosis, inflammation, portal vein and sinusoidal constriction and ballooning. Necrotic, ballooned and inflamed are shown in Figure 2. These results demonstrate aqueous methanolic extract provides protection if pretreatment was administered to mice before paracetamol injection and significant hepatitis can be seen in livers where pretreatments of extract were not provided.

Phytochemical screening of leaves of $M$. nigra revealed the presence of important phytoconsitutents as shown in Table III. Flavonoids are important compounds in plants and have previously reported to have hepatoprotective activity. In our study moderate amount of flavonoids was present in leaves of the plant. Qualitative determination of these flavonoids was conducted by HPLC analysis.

The results of HPLC chromatogram can be compared with standard retentions times according to Saddiqeet al., 2011. Aqueous methanolic extract of M. nigra showed presence of luteolin (1.96 $\mathrm{min})$, quercetin (2.05 $\mathrm{min})$ and isorhamnetin $(2.74 \mathrm{~min})$ as shown in the Figure 3.

\section{Discussion}

M. nigra is popular and widely distributed specie of Moraceae family. In this study hepatoprotective activity of leaves of $M$. nigra was evaluated by using mice as experimental animals. Aqueous methanolic extract of M. nigrawith $250 \mathrm{mg} / \mathrm{kg}$ reduces elevated ALT by $55 \%$ $(\mathrm{p}<0.001)$, AST by $59 \%(\mathrm{p}<0.001)$, ALP by $30 \%(\mathrm{p}<0.01)$ and TBR by $54 \%(\mathrm{p}<0.01)$ as compared to paracetamol control. At $500 \mathrm{mg} / \mathrm{kg}$ dose, elevated ALT reduced by 


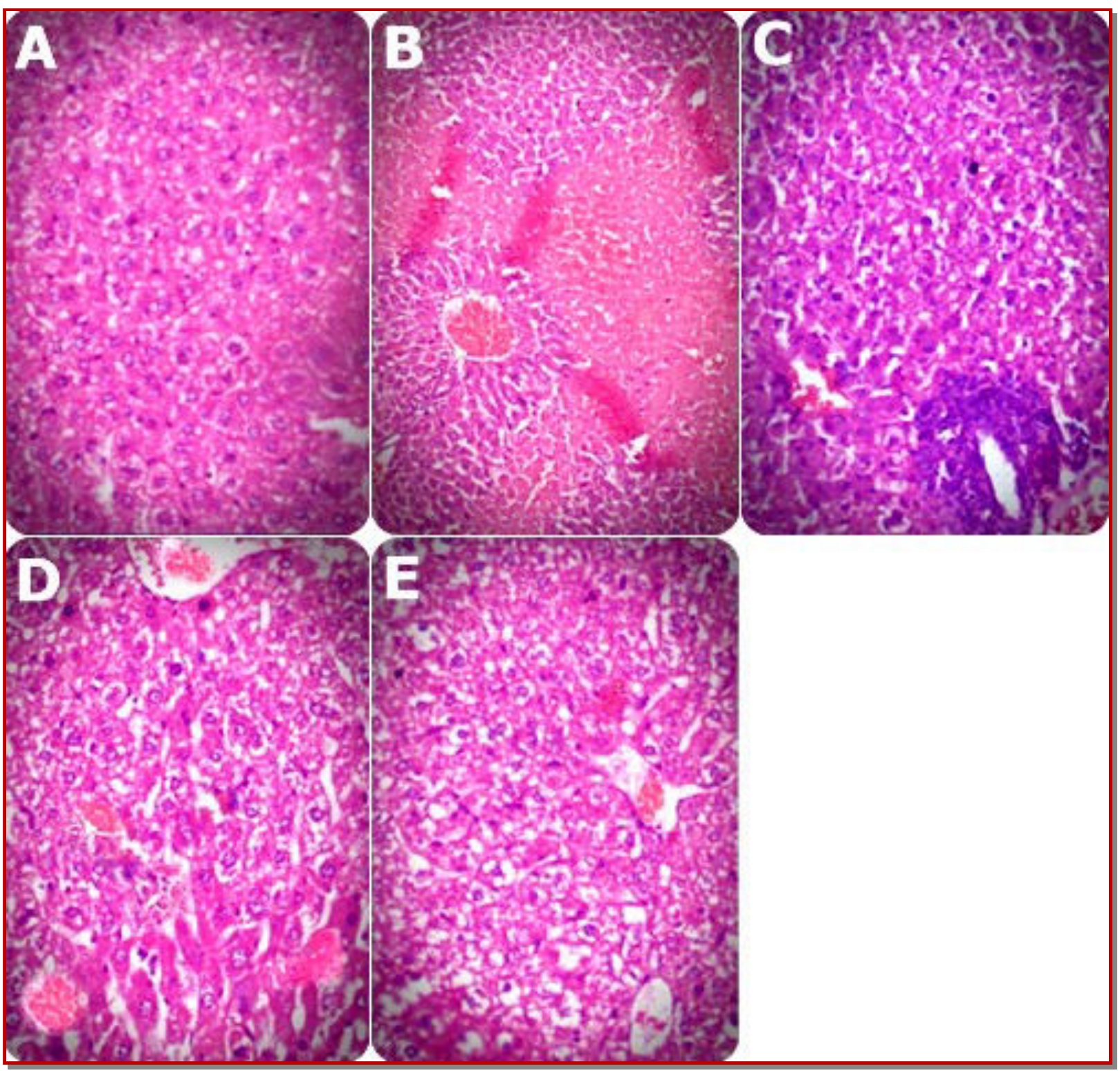

Figure 2: Histopathological pictures of (A) Normal hepatocytes (B) Paracetamol treated group, marked inflammation, necrosis, sinusoidal constrictions and ballooning (C) Silymarin treated group, improvement in necrosis, inflammation, ballooning and moderate dilatation of sinusoids (D) Extract $250 \mathrm{mg} / \mathrm{kg}$ treated group, mild inflammation ballooning and moderate sinusoidal dilatation (E) Extract $500 \mathrm{mg} / \mathrm{kg}$ treated group, moderated inflammation, mild ballooning, mild necrosis and moderate sinusoidal dilatation

$60 \%(\mathrm{p}<0.001)$, AST by $60 \%(\mathrm{p}<0.001)$, ALP by $34 \%$ $(\mathrm{p}<0.001)$ and TBR by $54 \%(\mathrm{p}<0.01)$ as compared to paracetamol control. There is insignificant $(p>0.05)$ difference between two doses with exception of ALP whose reduction is higher with $500 \mathrm{mg} / \mathrm{kg}(\mathrm{p}<0.001)$ as compared to $250 \mathrm{mg} / \mathrm{kg}(\mathrm{p}<0.01)$. These results are also comparable to that of silymarin $(\mathrm{p}<0.001$, as compared to paracetamol control). Hepatoprotective potential of M. nigra might be due to presence of flavonoids, phenols and saponins; the phytoconstituents determined by phytochemical screening. It has been documented that flavonoids have very important contribution for hepatoprotective action. Therefore, qualitative investiga -tion of flavonoids was conducted through isocratic flow HPLC. The results of this qualitative investigation revealed the presence of luteolin, quercetin and isorham -netin in aqueous methanolic extract of $M$. nigra. Luteolin (Domitrovićet al., 2009), isorhamnetin (Kim et al., 2012) and quercetin (Janbazet al., 2004), all are famous for its anti-oxidant and hepatoprotective potential. Due to its edible nature, easy accessibility and economical factor, M. nigra can be a good source of active continents having tolerable potential for liver health.

This plant also contains alkaloids as shown in phyto- 


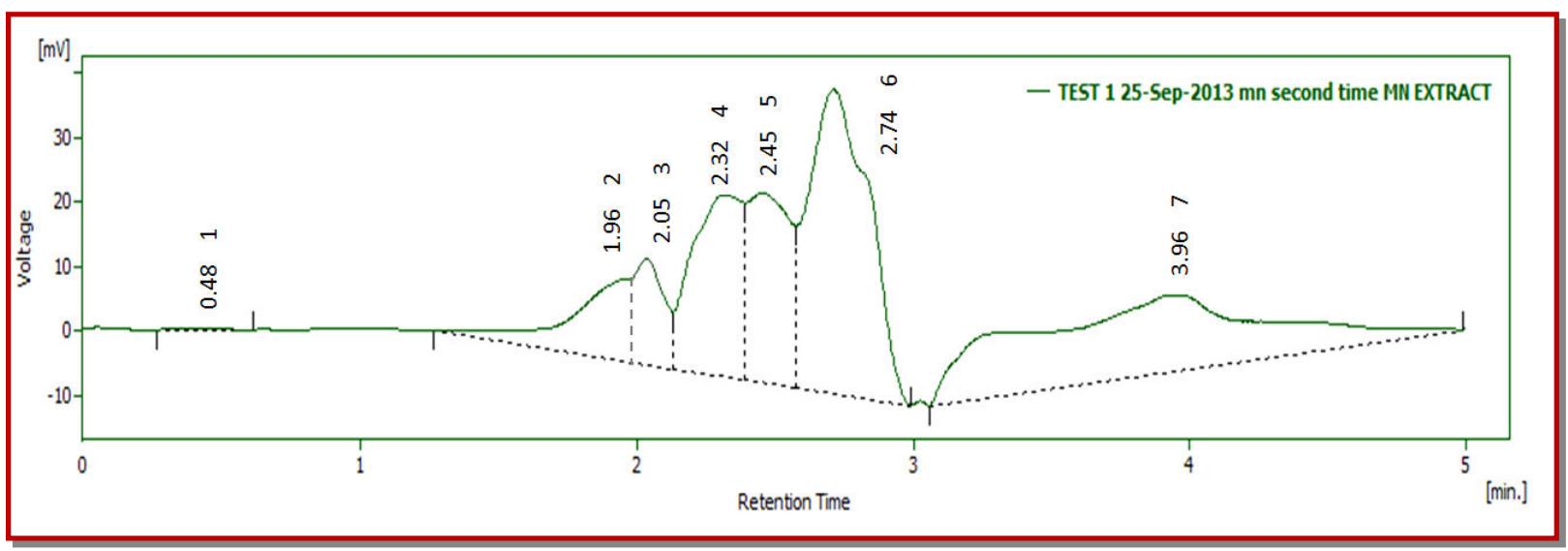

Figure 3: HPLC Chromatogram of aqueous methanolic extract of Morus nigrashowing presence of quercetin, luteolin and isorhamnetin

chemistry of plant in our study. The alkaloids may be hepatotoxic at higher doses (Ali et al., 2013), so there is need to determine its dose for hepatoprotective action. The possible mechanism of action may be due to free radical scavenger and anti-oxidant activities of identified compound (An et al., 2005; Oh et al., 2004).

\section{Conclusion}

Previous traditional hepatoprective use, HPLC analysis and animal testing provide evidence that $M$. nigra has hepatoprotective activity against paracetamol-induced liver injury in mice.

\section{Acknowledgement}

Authors are thankful to Qaisar Mahmood and Asif Masud for their contribution to accomplish this study.

\section{References}

Abbasi AM, Khan MA, Ahmad M, Zafar M, Khan H, Muhammad N, Sultana S. Medicinal plants used for the treatment of jaundice and hepatitis based on socio-economic documentation. Afr J Biotechnol. 2009; 8: 1643-50.

Ahmad M, Mahmood Q, Gulzar K, Akhtar MS, Saleem M, Qadir MI. Antihyperlipidaemic and hepatoprotective activity of Dodonaea viscosa leaves extracts in alloxaninduced diabetic rabbits (Oryctolagus cuniculus). Paki Vet J. 2012; 32: 50-54.

Akhtar MS, Asjad HMM, Bashir S, Malik A, Khalid R, Gulzar F, Irshad N. Evaluation of anti-oxidant and hepatoprotective effects of Khamira Gaozaban Ambri Jadwar Ood Saleeb Wala (KGA). Bangladesh J Pharmacol. 2013; 8: 44-48.

Ali M, Qadir MI, Saleem M, Janbaz KH, Gul H, Hussain L, Ahmed B. Hepatoprotective potential of Convolvulus arvensis against paracetamol-induced hepatotoxicity. Bangladesh J Pharmacol. 2013; 8: 300-04.

Amin N, Qadir MI, Khan TJ, Abbas G, Ahmad B, Janbaz KH, Ali M. Antibacterial activity of Vacuum liquid chromatography (VLC) isolated fractions of chloroform extracts of seeds of Achyranthes aspera. J Chem Soc Pak. 2012;
34: 589-92.

An RB, Kim HC, Tian YH, Kim YC. Free radical scavenging and hepatoprotective constituents from the leaves of Juglanssinensis. Arch Pharmacal Res. 2005; 28: 529-33.

Bag AK, Mumtaz SMF. Hepatoprotective and nephroprotective activity of hydroalcoholic extract of Ipomoea staphylina leaves. Bangladesh J Pharmacol. 2013; 8: 263-68.

Balamurugan G, Muthusamy P. Observation of the Hepatoprotective and anti-oxidant activities of Trianthema decandra Linn. (Vallaisharunnai) roots on carbon tetrachloridetreated rats. Bangladesh J Pharmacol. 2008; 3: 83-89.

Domitrović R, Jakovac H, Milin Č, Radošević-Stašić B. Doseand time-dependent effects of luteolin on carbon tetrachloride-induced hepatotoxicity in mice. Exp Toxicol Pathol. 2009; 61: 581-89.

Ehsan O, Qadir MI, Malik SA, Abbassi WS, Ahmad B. Efficacy of nanogold-insulin as a hypoglycemic agent. J Chem Soc Pak. 2012; 34: 365-70.

Fakhree MAA, Nazemiyeh $H$. Are anthocyanins and flavonoids responsible for the blood pressure lowering effect and antiplatelet activity of Morus nigra? Biomed Int. 2012; 2: 97-98.

Farhan H, Rammal H, Hijazi A, Badran B. Preliminary phytochemical screening and extraction of polyphenol from stems and leaves of a Lebanese plant Malva parviflora L. Int J Curr Pharm Res. 2012; 4: 55-59.

Girish C, Koner BC, Jayanthi S, Ramachandra Rao K, Rajesh B, Pradhan SC. Hepatoprotective activity of picroliv, curcumin and ellagic acid compared to silymarin on paracetamol induced liver toxicity in mice. Fundam Clin Pharmacol. 2009; 23: 735-45.

Hegde K, Joshi AB. Hepatoprotective and antioxidant effect of Carissa spinarum root extract against $\mathrm{CCl}_{4}$ and paracetamol induced hepatic damage in rats. Bangladesh J Pharmacol. 2010; 5: 73-76.

Hosseinzadeh H, Sadeghi A. Antihyperglycemic effects of Morus nigra and Morus alba in mice. Pharm Pharmacol Lett. 1999; 9: 63-65.

Hussain A, Khalid SH, Qadir MI, Massud A, Ali M, Khan IU, Saleem M, Iqbal MS, Asghar S, Gul H. Water uptake and drug release behaviour of methyl methacrylate-co-itaconic 
acid [P(MMA/IA)] hydrogels cross-linked with methylene bis-acrylamide. J Drug Deliv Sci Tech. 2011; 21: 249-55.

Iwalokun BA, Efedede BU, Alabi-Sofunde JA, Oduala T, Magbagbeola OA, Akinwande AI.. Hepatoprotective and anti-oxidant activities of Vernonia amygdalina on acetaminophen-induced hepatic damage in mice. J Med Food. 2006; 9: 524-30.

Jain A, Soni M, Deb L, Jain A, Rout SP, Gupta VP, Krishna KL. Anti-oxidant and hepatoprotective activity of ethanolic and aqueous extracts of Momordica dioica Roxb. Leaves. J Ethnopharmacol. 2008; 115: 61-66.

Janbaz KH, Nisar U, Ashraf M, Qadir MI. Spasmolytic, broncho -dilator and anti-oxidant activities of Erythrina superosa Roxb. Acta Pol Pharm. 2012; 69: 1111-17.

Janbaz KH, Saeed SA, Gilani AH. Studies on the protective effects of caffeic acid and quercetin on chemical-induced hepatotoxicity in rodents. Phytomedicine 2004; 11: 424-30.

Javed F, Qadir MI, Janbaz KH, Ali M. Novel drugs from marine microorganisms. Cr Rev Microbiol. 2011; 37: 245-49.

Khalid SH, Qadir MI, Massud A, Ali M, Rasool MH. Effect of degree of cross-linking on swelling and drug release behaviour of poly (methyl methacrylate-co-itaconic acid) $[\mathrm{P}$ (MMA/IA)] hydrogels for site specific drug delivery. J Drug Deliv Sci Tech. 2009; 19: 413-18.

Khan AZ, Mohammad A, Iqbal Z, Anis I, Shah MR, Nadeem S, Rabnawaz M, Shahidullah A, Khan H, Khan I. Molecular docking of viscosine as a new lipoxygenase inhibitor isolated from Dodonaea viscose. Bangladesh J Pharmacol. 2013; 8: 36-39.

Khan YH, Mallhi TH, Sarriff A, Khan AH. Osteoporosis: Are healthcare professionals missing an opportunity. Springer Plus. 2013; 2: 1-5.

Khan YH, Sarriff A, Khan AH. A review of knowledge, attitude and practices (Kap) of community population towards osteoporosis. J Appl Pharm. 2012; 4: 628.

Kim DW, Kim KM, Choi JS, Lee SM. Isorhamnetin-3-Ogalactoside protects against $\mathrm{CCl}_{4}$-induced hepatic injury in mice. Biomol Ther. 2012; 20: 406-12.

Kumar V, Chauhan S. Mulberry: Life enhancer. J Med Plant Res. 2008; 2: 271-78.

Malik MNH, Alamgeer US, Qayyum A, Samreen S. Phytochemical analysis and cardiac depressant activity of aqueous methanolic extract of Morus nigra L. Fruit. J Appl Pharm Sci. 2012; 2: 39-41.

Masood MI, Qadir MI, Shirazi JH, Khan IU. Beneficial effects of lactic acid bacteria on human beings. Cr Rev Microbiol. 2011; 37: 91-98.

Mazimba O, Majinda RR, Motlhanka D. Anti-oxidant and antibacterial constituents from Morus nigra. Afr J Pharm Pharmacol. 2011; 5: 751-54.

Naz S, Qadir MI, Ali M, Janbaz KH. Nanotechnology for imaging and drug delivery in cancer. J Chem Soc Pak. 2011; 34: 107-11.
Oh H, Kim DH, Cho JH, Kim YC. Hepatoprotective and free radical scavenging activities of phenolic petrosins and flavonoids isolated from Equisetum arvense. J Ethnopharmacol. 2004; 95: 421-24.

Özgen M, Serçe S, Kaya C. Phytochemical and anti-oxidant properties of anthocyanin-rich Morus nigra and Morus rubra fruits. Sci Hortic. 2009; 119: 275-79.

Padilha MM, Vilela FC, da Silva MJD, dos Santos MH, Alvesda-Silva G, Giusti-Paiva A. Antinociceptive effect of the extract of Morus nigra leaves in mice. J Med Food. 2009; 12: 1381-85.

Padilha MM, Vilela FC, Rocha CQ, Dias MJ, Soncini R, dos Santos MH, da-Silva GA, Giusti-Paiva A. Anti-inflammatory properties of Morus nigra leaves. Phytother Res. 2010; 24: 1496-1500 .

Pawlowska AM, Oleszek W, Braca A. Quali-quantitative analyses of flavonoids of Morus nigra L. and Morus alba $\mathrm{L}$. (Moraceae) fruits. J Agric Food Chem. 2008; 56: 3377-80.

Qadir MI. Medicinal and cosmetological importance of Aloe vera. Int J Nat Ther. 2009; 2: 21-26.

Qadir MI. Medicinal values of ginger. Int J Nat Ther. 2009; 3: 19-22.

Qadir MI. Qadirvirtide. Pak J Pharm Sci. 2011; 24: 593-95.

Sabir SM, Rocha JBT. Anti-oxidant and hepatoprotective activity of aqueous extract of Solanum fastigiatum (false "Jurubeba") against paracetamol-induced liver damage in mice. J Ethnopharmacol. 2008; 120: 226-32.

Saboo SS, Tapadiya G, Farooqui IA, Khadabadi SS. Free radical scavenging, in vivo anti-oxidant and Hepatoprotective activity of folk medicine Trichodesma sedgwicki anum. Bangladesh J Pharmacol. 2013; 8: 58-64.

Saddiqe Z, Naeem I, Maimoona A, Sautreau A, Hellio C. Assay of flavonoid aglycones with HPLC in four species of genus Hypericum. J Med Plants Res. 2011; 5: 1526-30.

Sadeque MZ, Begum ZA. Protective effect of dried fruits of Carica papaya on hepatotoxicity in rat. Bangladesh J Pharmacol. 2010; 5: 48-50.

Shanmugasundaram P, Venkataraman S. Hepatoprotective and anti-oxidant effects of Hygrophila auriculata (K. Schum) Heine Acanthaceae root extract. J Ethnopharmacol. 2006; 104: 124-28.

Thakare SP, Jain HN, Patil SD, Upadhyay UM. Hepatoprotective effect of Cocculus hirsutus on bile duct ligation-induced liver fibrosis in Albino Wistar rats. Bangladesh J Pharmacol. 2009; 4: 126-30.

Vimal V, Devaki T. Hepatoprotective effect of allicin on tissue defense system in galactosamine/endotoxin challenged rats. J Ethnopharmacol. 2004; 90: 151-54.

Volpato GT, Calderon IMP, Sinzato S, Campos KE, Rudge MVC, Damasceno DC. Effect of Morus nigra aqueous extract treatment on the maternal-fetal outcome, oxidative stress status and lipid profile of streptozotocin-induced diabetic rats. J Ethnopharmacol. 2011; 138: 691-96. 